\title{
Human chorionic gonadotropin is an immune modulator and can prevent autoimmune diabetes in NOD mice
}

\author{
L.-Y. Khil • H.-S. Jun • H. Kwon • J. K. Yoo • S. Kim • \\ A. L. Notkins • J.-W. Yoon
}

Received: 22 March 2007 / Accepted: 19 June 2007 / Published online: 4 August 2007

(C) Springer-Verlag 2007

\begin{abstract}
Aims/hypothesis Expression of $\mathrm{T}$ helper (Th)1 cytokine mRNA in pregnant women is known to be inversely correlated with serum human chorionic gonadotropin (hCG). Type 1 diabetes is a Th1-mediated autoimmune disease, in which intervention at an early stage of the autoimmune process can prevent disease progression. We hypothesised that immune modulation by treating young NOD mice with hCG may prevent diabetes.

Methods Female NOD mice were treated with hCG or recombinant hCG from 3 to 15 weeks of age and the incidence of diabetes and development of insulitis was determined. $\mathrm{CD}^{+}$and $\mathrm{CD}^{+}{ }^{+} \mathrm{T}$ cell populations, $\mathrm{T}$ cell proliferation, cytokine production and $\mathrm{CD} 4^{+} \mathrm{CD} 25^{+}$regula-
\end{abstract}

L.-Y. Khil, H.-S Jun and H. Kwon contributed equally to this work.

Ji-Won Yoon sadly passed away on 6 April 2006.

L.-Y. Khil $\cdot$ H.-S. Jun $\cdot$ H. Kwon · J. K. Yoo $\cdot$ S. Kim · J.-W. Yoon Department of Microbiology and Infectious Diseases,

Faculty of Medicine, University of Calgary,

Calgary, Alberta, Canada

H.-S. Jun $(\bowtie) \cdot$ J.-W. Yoon

Rosalind Franklin Comprehensive Diabetes Center,

Chicago Medical School,

3333 Green Bay Road,

North Chicago, IL 60064, USA

e-mail: hee-sook.jeon@rosalindfranklin.edu

\section{A. L. Notkins}

Experimental Medicine Section, Oral Infection

and Immunity Branch, NIDCR, NIH,

Bethesda, MD, USA tory $\mathrm{T}$ cells were examined and adoptive transfer experiments were performed.

Results Both purified and recombinant $\mathrm{hCG}$ prevented development of diabetes in NOD mice. hCG decreased the proportion and number of $\mathrm{CD}^{+}$and $\mathrm{CD}^{+} \mathrm{T}$ cells and inhibited $\mathrm{T}$ cell proliferative responses against beta cell antigens. hCG treatment suppressed IFN- $\gamma$ production, but increased IL-10 and TGF- $\beta$ production in splenocytes stimulated with anti-CD3 antibody. hCG treatment also suppressed TNF- $\alpha$ production in splenocytes stimulated with lipopolysaccharide. Furthermore, hCG treatment increased the $\mathrm{CD} 4^{+} \mathrm{CD} 25^{+} / \mathrm{CD} 4^{+} \mathrm{T}$ cell ratio in spleen and pancreatic lymph nodes. Depletion of $\mathrm{CD} 4^{+} \mathrm{CD} 25^{+} \mathrm{T}$ cells from splenocytes of hCG-treated NOD mice abolished their preventive effect on diabetes transfer.

Conclusions/interpretation We conclude that hCG has an immunomodulatory effect by downregulating effector cells, including Th1 cells, $\mathrm{CD} 8^{+} \mathrm{T}$ cells and macrophages, and increasing the $\mathrm{CD} 4{ }^{+} \mathrm{CD} 25^{+} / \mathrm{CD} 4^{+} \mathrm{T}$ cell ratio, thus preventing autoimmune diabetes in NOD mice.

Keywords Autoimmune disease - Cytokines .

Human chorionic gonadotropin - Immune regulation .

Insulitis $\cdot$ NOD mice $\cdot$ Regulatory T cells $\cdot$ T cells $\cdot$

Th1 immune response $\cdot$ Type 1 diabetes

$\begin{array}{ll}\text { Abbreviations } \\ \text { HCG } & \text { human chorionic gonadotropin } \\ \text { LPS } & \text { lipopolysaccharide } \\ \text { MIN } & \text { mouse insulinoma } \\ \text { rhCG } & \text { recombinant human chorionic gonadotropin } \\ \text { SCID } & \text { severe combined immunodeficient } \\ \text { Th } & \text { T helper }\end{array}$




\section{Introduction}

Human chorionic gonadotropin ( $\mathrm{hCG}$ ) is a heterodimeric placental glycoprotein required to maintain pregnancy. The level of hCG increases during the first trimester of pregnancy and decreases to $10 \%$ of the peak value during the second and third trimesters [1]. The symptoms of autoimmune diseases such as rheumatoid arthritis, Crohn's disease and multiple sclerosis are attenuated during pregnancy [2-4]. In pregnant women, the expression of T helper (Th) 1 cytokine mRNA such as $I L 2$ and $I F N-\gamma$ (also known as $I F N G$ ) is significantly decreased, while expression of IL18 mRNA, an inducer of IFN- $\gamma$ in T lymphocytes and natural killer cells, is inversely correlated with serum levels of hCG [5]. This suggests that hCG may have an immunoregulatory role in addition to its classical reproductive role in the maintenance of pregnancy. There is further evidence to support this view in animal models. Purified hCG and a 400-2,000 Da fraction of clinical grade hCG were shown to prevent diabetes in mice [6]. Another study showed that treatment with hCG prevented the wasting and death of transgenic mice carrying human immunodeficiency virus genes [7]. Recent studies have shown that this wasting syndrome is due in part to high levels of TNF- $\alpha$, which can be suppressed by treatment with hCG [8]. However, the mechanisms by which hCG prevents autoimmune disease are not clearly understood.

Type 1 diabetes results from the destruction of pancreatic beta cells by $\mathrm{T}$ cell-mediated autoimmune responses, which are thought to result from an autoimmune inflammatory process mediated by autoreactive Th1 cells and their secreted cytokines [9-11]. We hypothesised that treatment of prediabetic individuals with hCG might impede the autoimmune processes by modulating immune responses, resulting in the prevention of autoimmune type 1 diabetes. We tested this possibility in the NOD mouse, which is a widely used animal model for the study of human autoimmune type 1 diabetes. We report that hCG treatment downregulated Th1 cytokines and macrophage proinflammatory cytokines and increased Th 2 cytokines and TGF- $\beta$. In addition, hCG decreased $\mathrm{CD}^{+}$and $\mathrm{CD} 8^{+} \mathrm{T}$ cells, but increased the ratio of $\mathrm{CD} 4^{+} \mathrm{CD} 25^{+}$regulatory $\mathrm{T}$ cells $/ \mathrm{CD} 4^{+} \mathrm{T}$ cells.

\section{Methods}

Animals Female NOD and NOD/severe combined immunodeficient (NOD.SCID) mice were obtained from The Jackson Laboratory (Bar Harbor, ME, USA). The animals were maintained under specific pathogen-free conditions and provided with free access to sterile food and water at the Animal Resources Centre, Faculty of Medicine, University of Calgary. The use and care of the animals were approved by the Animal Care Committee, Faculty of Medicine, University of Calgary.

Treatment with $h C G$ and monitoring of diabetes onset Recombinant hCG (rhCG) and hCG from the urine of pregnant women were obtained from Sigma (St Louis, MO, USA). Purity was determined by $12 \%$ SDS-PAGE followed by staining using a silver staining kit (Bio-Rad, Hercules, CA, USA). The pattern of protein bands in hCG was the same as in rhCG, indicating that the hCG did not contain other apparent protein contaminants compared with rhCG. NOD female mice ( 3 or 10 weeks of age) were injected i.p. with $50 \mathrm{IU}$ hCG or rhCG (giving a blood concentration comparable with that in pregnant humans) in $200 \mu \mathrm{l}$ PBS per mouse or with PBS alone, 5 times per week for 12 weeks. The development of diabetes was monitored by urine glucose measurements using Diastix (Bayer, West Haven, CT, USA) every week and positive glycosuria was confirmed by hyperglycaemia (blood glucose level $>16.7 \mathrm{mmol} / \mathrm{l}$ ). If mice became diabetic during the experiment, they were killed according to guidelines of the animal care protocol.

Histology The pancreata were removed from hCG- or PBStreated NOD mice at 15 or 30 weeks of age. The pancreata were fixed with $10 \%$ buffered formalin, embedded in paraffin and sectioned at $4.5 \mu \mathrm{m}$ intervals. More than 500 serial sections were prepared from each pancreas and every 20th section was stained with haematoxylin and eosin [12]. The degree of insulitis was scored as one of four categories: intact islet; $<25 \%$ of the islet infiltrated; 25 to $50 \%$ of the islet infiltrated; 50 to $75 \%$ of the islet infiltrated; and $>75 \%$ of the islet infiltrated. The degree of insulitis in 20 to 25 islets per mouse was independently evaluated by two investigators.

$T$ cell proliferation To examine the proliferation of $\mathrm{T}$ cells, splenocytes $\left(1 \times 10^{5}\right.$ cells) were cultured for $96 \mathrm{~h}$ in the presence or absence of anti-CD3 antibody $(0.5 \mu \mathrm{g} / \mathrm{ml})$ or mouse insulinoma (MIN)6N8a cell extract $(25 \mu \mathrm{g} /$ well) in $200 \mu \mathrm{l}$ of complete RPMI medium containing $10 \%$ fetal bovine serum and antibiotics in a 96-well microplate. To prepare MIN6N8a cell extract, MIN6N8a cells were collected by trypsinisation, suspended in PBS and sonicated for $3 \mathrm{~min}$. The cells were pulsed with $\left[{ }^{3} \mathrm{H}\right]$ thymidine (37 kBq/well) for $16 \mathrm{~h}$ of incubation and then harvested. The incorporation of $\left[{ }^{3} \mathrm{H}\right]$ thymidine was measured by liquid scintillation counting [12]. A stimulation index was calculated by dividing the cpm from the stimulated group by the cpm from the unstimulated group.

Quantitative ELISA for cytokine production Splenocytes $\left(1 \times 10^{6}\right.$ cells) from 10 -week-old female NOD mice treated with PBS or hCG were stimulated with anti-CD3 antibody 
$(0.5 \mu \mathrm{g} / \mathrm{ml})$ for IFN- $\gamma$, IL-4, IL-10 and TGF- $\beta$ or lipopolysaccharide (LPS; $10 \mathrm{ng} / \mathrm{ml}$ ) for TNF- $\alpha$ for indicated times in $1 \mathrm{ml}$ of complete RPMI medium. The supernatant fraction was collected and cytokine release was measured using a specific ELISA kit (Quantikine; R \& D Systems, Minneapolis, MN, USA) according to the manufacturer's protocol.

FACS analysis Splenocytes and pancreatic lymph node cells were isolated from hCG or PBS-treated female NOD mice at 10 weeks of age. To examine the $\mathrm{CD} 4^{+}$and $\mathrm{CD} 8^{+} \mathrm{T}$ cell populations, cells $\left(1 \times 10^{6}\right)$ were incubated with FITClabelled anti-CD4 and phycoerythrin-labelled anti-CD8 antibodies (Pharmingen, Mississauga, ON, Canada) for $30 \mathrm{~min}$ at $4^{\circ} \mathrm{C}$ in staining buffer $(1 \%$ fetal bovine serum and $0.1 \%$ sodium azide in PBS). To examine the macrophage population, cells were incubated with FITC-labelled anti-CD11b antibody (Pharmingen). To examine the $\mathrm{CD} 4^{+} \mathrm{CD} 25^{+} \mathrm{T}$ cell population, cells were incubated with FITC-labelled anti-CD4 and phycoerythrin-labelled antiCD25 antibodies. To examine the natural killer $\mathrm{T}$ and $\mathrm{CD} 4{ }^{+} \mathrm{CD} 62 \mathrm{~L}^{+}$regulatory cell populations, splenocytes and lymph node cells were double-stained with FITC-labelled anti-CD3 and biotin-labelled DX5 antibodies or FITClabelled anti-CD4 and biotin-labelled anti-CD62L antibodies, respectively, followed by phycoerythrin-labelled streptavidin. The cells were washed with staining buffer and analysed by FACS [13].

Adoptive transfer Splenocytes were isolated from hCG-, rhCG- or PBS-treated mice at 15 weeks of age, checked for viability under the microscope and transferred (i.v.) into 6-week-old NOD.SCID mice as described elsewhere [14]. To examine the preventive effect, splenocytes from hCG- or PBS-treated mice were transferred along with same number of diabetic splenocytes. To determine whether $\mathrm{CD}^{+} \mathrm{T}$ cell population contained regulatory $\mathrm{T}$ cells, splenocytes were isolated from hCG- or PBS-treated NOD mice and CD $8^{+} \mathrm{T}$ cells were depleted with anti-CD8 antibody-linked micromagnetic beads (Miltenyi Biotec, Auburn, CA, USA). The $\mathrm{CD}^{+} \mathrm{T}$ cell-depleted splenocytes $\left(1 \times 10^{7}\right.$ cells $)$ were cotransferred with splenocytes from diabetic NOD mice $\left(0.5 \times 10^{7}\right.$ cells, $2: 1$ ratio $)$. To examine the role of $\mathrm{CD} 4^{+} \mathrm{CD} 25^{+} \mathrm{T}$ cells, splenocytes were isolated from hCGtreated NOD mice and $\mathrm{CD} 25^{+} \mathrm{T}$ cells were depleted using anti-CD25 antibody-linked micromagnetic beads (Miltenyi Biotec). The $\mathrm{CD} 25^{+} \mathrm{T}$ cell-depleted splenocytes or total splenocytes $\left(1 \times 10^{7}\right.$ cells per recipient) were transferred. In addition, $\mathrm{CD}^{+}$- and $\mathrm{CD} 25^{+}$-depleted splenocytes were cotransferred with splenocytes from diabetic NOD mice. As a positive control, splenocytes from acutely diabetic mice were injected into NOD.SCID mice. The development of diabetes in NOD.SCID recipients was monitored by measuring urine glucose twice weekly and confirmed by measurement of blood glucose levels.

Statistical analyses The statistical significance of the differences between groups was analysed by two-tailed Student's $t$ test. Normality of data was verified by the Kolmogorov-Smirnov test. A level of $p<0.05$ was accepted as significant. For comparison of incidence of diabetes, the two-tailed log-rank test was used.

\section{Results}

Purified hCG prevents autoimmune diabetes in NOD mice NOD mice were treated with hCG purified from the urine of pregnant women (50 $\mathrm{U}$ per mouse, 5 days per week) beginning at 3 weeks of age for 12 weeks and monitored for the development of diabetes. None of the hCG-treated mice developed diabetes ( 0 of 12), whereas $83 \%$ (10 of 12) of the PBS-treated mice developed diabetes by 30 weeks of age (Fig. 1a). An increase in ovarian size and a transient increase in body weight were observed in hCG-treated mice (data not shown). No other physical or behavioural abnormalities were observed. When we examined the islets for insulitis at 15 weeks of age, we found that most of the islets from hCG-treated mice were intact, whereas the majority of the islets from PBS-treated mice showed severe insulitis (Fig. 1b,c). On examining the islets at 30 weeks of age, i.e. 15 weeks after termination of hCG treatment, we found that insulitis was not significantly different from that at 15 weeks of age (Fig. 1c). To determine whether hCG inhibits the development of diabetes after inflammation has already occurred, we injected hCG into NOD mice beginning at 10 weeks of age. The incidence of diabetes was significantly reduced in hCG-treated mice, with $33 \%$ of hCG-treated NOD mice (4 of 12) developing diabetes as compared with $83 \%$ of PBS-treated NOD mice (10 of 12; Fig. 1d).

To determine whether splenocytes from hCG-treated NOD mice have the ability to transfer diabetes, splenocytes from hCG- or PBS-treated NOD mice at 15 weeks of age were transferred into NOD.SCID mice and the incidence of diabetes was determined. All of the recipients (6 of 6 ) of splenocytes from PBS-treated or diabetic NOD mice developed diabetes by 8 weeks after transfer, whereas none ( 0 of 7 ) of the recipients of splenocytes from hCG-treated mice developed diabetes (Fig. 2a). To determine whether splenocytes from hCG-treated NOD mice have the ability to inhibit the adoptive transfer of diabetes, we co-transferred splenocytes from hCG- or PBS-treated NOD mice along with splenocytes from acutely diabetic NOD mice into NOD. SCID mice. All of the recipients ( 6 of 6 ) of a combination of 
a

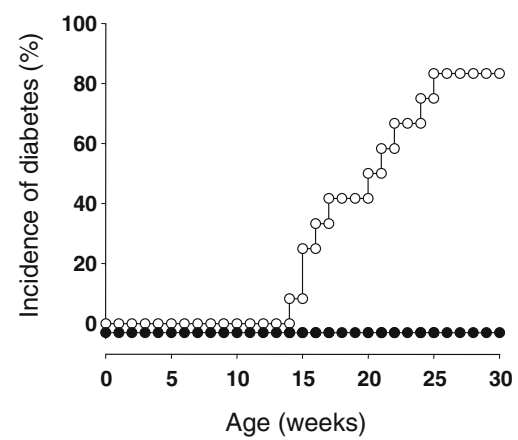

C

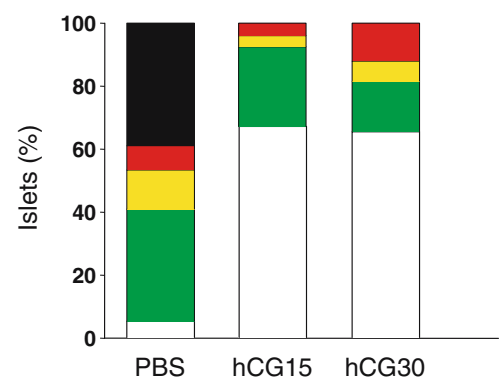

b

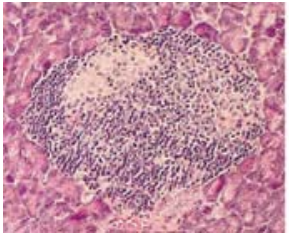

PBS-NOD

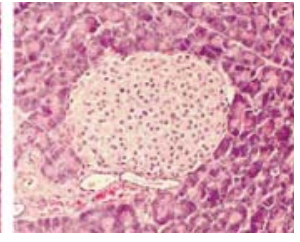

hCG-NOD

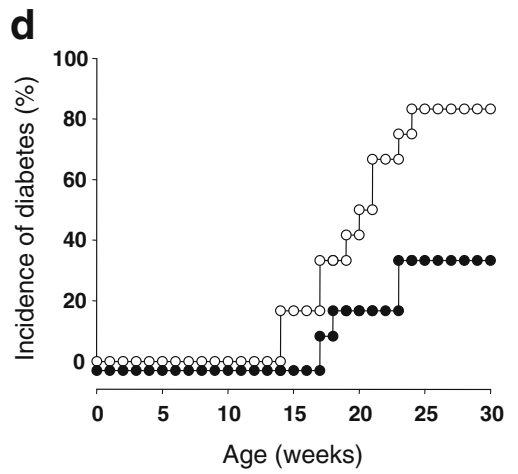

30 weeks of age. Photomicrographs (b) were taken of haematoxylin and eosin-stained pancreatic sections from 15-week-old mice. Original magnification $\times 250$. c Degree of insulitis was examined in at least 20 islets per mouse ( $n=5$ per group). Insulitis grading ( $\%$ of islet infiltrated): white column, intact islet; green column, less than $25 \%$; yellow column, 25-50\%; red column, 50-75\%; black column, $>75 \%$

cells, $\mathrm{CD} 8^{+} \mathrm{T}$ cells and $\mathrm{CD} 11 \mathrm{~b}^{+}$macrophages were examined in the spleen and pancreatic lymph nodes. The proportion (Fig. 4a) and number (Fig. 4b) of $\mathrm{CD}^{+}$and $\mathrm{CD} 8^{+} \mathrm{T}$ cells were decreased in the spleen and pancreatic lymph nodes of hCG-treated mice. There were no significant changes in the macrophage population (data not shown). We next examined the effect of hCG on the proliferative responses of $\mathrm{T}$ cells. Splenocytes from hCG- or PBS-treated mice were stimulated with anti-CD3 antibody or beta cell antigens (extract of MIN6N8a cells) and the proliferative response was examined. Strong $\mathrm{T}$ cell proliferative responses were seen with anti-CD3 antibody (Fig. 4c) and medium responses were seen with MIN6N8a cell extract (Fig. 4d). Responses against both of these antigens were significantly inhibited in hCG-treated NOD mice as compared with PBStreated NOD mice (Fig. 4c,d).

To determine whether hCG can induce regulatory $\mathrm{T}$ cell populations, the proportion and number of regulatory $\mathrm{T}$ cells were examined by flow cytometry in splenocytes and pancreatic lymph node cells from 10-week-old female NOD mice treated with hCG or PBS. The proportion of $\mathrm{CD} 4{ }^{+} \mathrm{CD} 25^{+}$ $\mathrm{T}$ cells in the $\mathrm{CD} 4^{+} \mathrm{T}$ population was significantly increased in the spleen and pancreatic lymph node (Fig. 5a), but the 
a

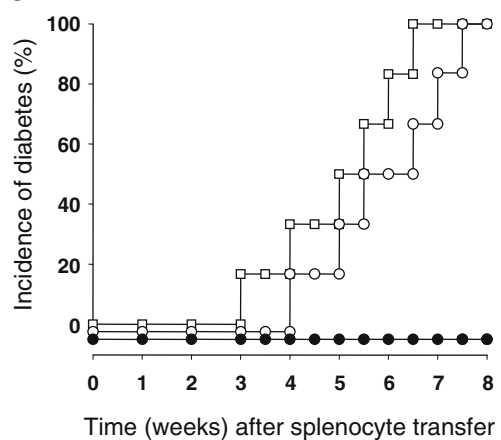

b

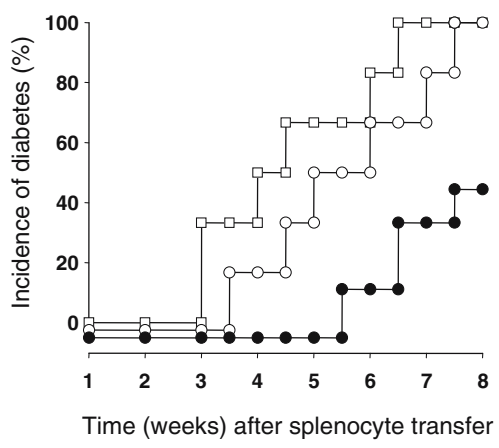

Fig. 2 Splenocytes from hCG-treated NOD mice prevent the transfer of diabetes. Splenocytes were isolated from PBS- or hCG-treated female NOD mice at 15 weeks of age. a Total splenocytes from either PBS-treated (open circles), hCG-treated (closed circles) or diabetic (open squares; control) mice were injected intravenously into NOD. SCID mice and the development of diabetes was monitored. b Total splenocytes from PBS-treated (open circles) or hCG-treated (closed circles) mice were mixed with splenocytes from acutely diabetic NOD mice in a 2:1 ratio and injected intravenously into NOD.SICD mice. The development of diabetes was monitored. Splenocytes from diabetic mice were injected as a control (open squares). $p<0.001$ (a) compared with recipients of PBS splenocytes, $n=6-7$ per group; $p<$ 0.05 (b) compared with recipients of PBS splenocytes+diabetic splenocytes, $n=6-9$ per group a

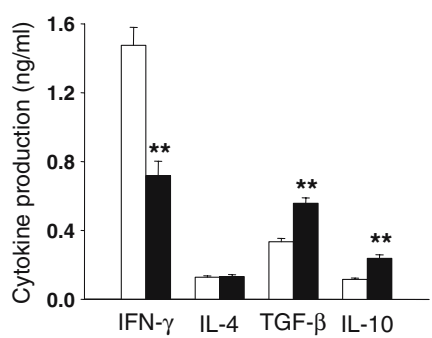

b

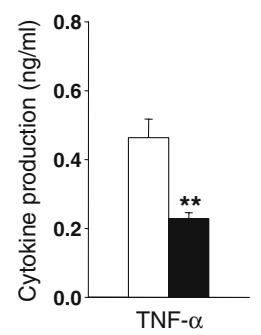

Fig. 3 Human CG treatment inhibits IFN- $\gamma$ and TNF- $\alpha$, but increases IL-10 and TGF- $\beta$ production. a Splenocytes from 10-week-old PBStreated (open bars) or hCG-treated (closed bars) female NOD mice were stimulated with anti-CD3 antibody for $24 \mathrm{~h}$ (IFN- $\gamma$ ), $48 \mathrm{~h}$ (IL-4 and IL-10) or $72 \mathrm{~h}$ (TGF- $\beta$ ). b Splenocytes were stimulated with LPS for $24 \mathrm{~h}$ for TNF- $\alpha$. The supernatants were collected and cytokines were measured by ELISA. $* * p<0.01$ compared with PBS-treated group, $n=7$ per group absolute number of $\mathrm{CD} 4^{+} \mathrm{CD} 25^{+} \mathrm{T}$ cells was not changed in hCG-treated NOD mice (Fig. 5b). Both the proportion and number of natural killer $\mathrm{T}$ cells and $\mathrm{CD} 4^{+} \mathrm{CD} 62 \mathrm{~L}^{+} \mathrm{T}$ cells remained unchanged in hCG-treated NOD mice compared with PBS-treated mice (data not shown).

$C D 4^{+}$and $C D 4^{+} C D 25^{+} T$ cells from hCG-treated mice protect against the development of diabetes To determine whether $\mathrm{CD} 4^{+} \mathrm{T}$ cells contain regulatory $\mathrm{T}$ cells that can prevent the transfer of diabetes, we co-transferred $\mathrm{CD} 8^{+} \mathrm{T}$ cell-depleted splenocytes from hCG- or PBS-treated NOD mice along with splenocytes from acutely diabetic NOD mice into NOD.SCID mice. All mice (6 of 6 ) that received $\mathrm{CD}^{+} \mathrm{T}$ cell-depleted splenocytes from PBS-treated NOD mice along with splenocytes from diabetic mice developed diabetes within 8 weeks after transfer. In contrast, only $33 \%$ (2 of 6) of mice that received $\mathrm{CD} 8^{+} \mathrm{T}$ cell-depleted splenocytes from hCG-treated NOD mice along with splenocytes from diabetic mice developed diabetes (Fig. 6a); this reduction is similar to the degree of prevention afforded by transfer of non-depleted splenocytes from hCG-treated mice along with splenocytes from diabetic NOD mice (Fig. 2b).

To determine whether $\mathrm{CD} 4{ }^{+} \mathrm{CD} 25^{+} \mathrm{T}$ cells are responsible for the prevention of diabetes, we depleted the $\mathrm{CD} 8^{+}$and $\mathrm{CD} 25^{+}$cell populations from splenocytes of hCG-treated NOD mice and co-transferred the remaining cells along with splenocytes from diabetic NOD mice into NOD.SCID recipients. All mice (6 of 6 ) that received $\mathrm{CD} 8^{+}$cell- and $\mathrm{CD} 25^{+}$cell-depleted splenocytes from hCG-treated NOD mice along with diabetogenic splenocytes developed diabetes (Fig. 6b), indicating that $\mathrm{CD} 4^{+} \mathrm{CD} 25^{+}$cells play an important role in the prevention of diabetes. We also depleted the $\mathrm{CD} 25^{+} \mathrm{T}$ cell population from splenocytes of hCG-treated NOD mice and transferred the remaining cells into NOD. SCID mice. All the recipients of $\mathrm{CD} 25^{+} \mathrm{T}$ cell-depleted splenocytes developed diabetes, whereas none of the recipients of splenocytes that were not depleted of $\mathrm{CD} 25^{+} \mathrm{T}$ cells developed diabetes (Fig. 6c).

Recombinant $h C G$ prevents autoimmune diabetes in NOD mice To determine whether rhCG has a similar effect on the control of autoimmune diabetes as purified hCG, we treated 3-week-old female NOD mice with rhCG and examined the incidence of diabetes, the incidence of diabetes by adoptive transfer and the production of cytokines. We found that $16.7 \%$ of mice treated with rhCG became diabetic, which was comparable to the incidence seen in mice treated with purified hCG. Moreover, neither splenocytes from hCG- nor those from rhCG-treated mice caused diabetes when transplanted into NOD.SCID mice. Both hCG and rhCG inhibited the production of IFN $-\gamma$ and TNF- $\alpha$, but neither changed the production of IL-4 (Table 1). 

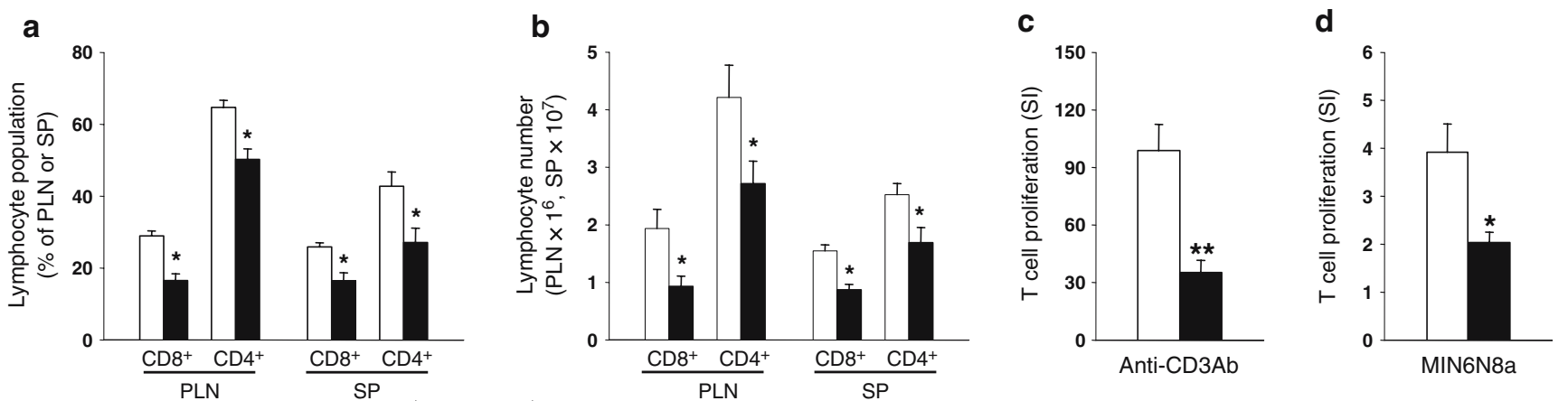

Fig. 4 hCG treatment decreases $\mathrm{CD} 4{ }^{+}$and $\mathrm{CD} 8^{+} \mathrm{T}$ cells and inhibits $\mathrm{T}$ cell proliferation. Pancreatic lymph node cells (PLN) and splenocytes (SP) from 10-week-old PBS-treated (open bars) or hCG-treated (closed bars) female NOD mice were stained with anti-CD4, anti-CD8 or anti-B220 antibodies and analysed by FACS. The a proportion and b number of $\mathrm{CD}^{+}$and $\mathrm{CD} 8{ }^{+} \mathrm{T}$ cells were calculated. Splenocytes

\section{Discussion}

hCG is required for the maintenance of pregnancy $[1,15]$. The symptoms of autoimmune disease can be attenuated in pregnant women $[2-4,16,17]$. It was previously found that purified hCG or a fraction of clinical grade hCG can prevent autoimmune diabetes in animal models [6]. However, the mechanisms by which hCG prevents autoimmune disease are not clearly known.

Here, we first examined the effect of hCG on the prevention of diabetes. Treatment of NOD mice with hCG before the development of insulitis resulted in complete prevention of diabetes, while treatment after the development of insulitis was partially effective, suggesting that hCG has a preventive effect before and after the onset of insulitis. In contrast to earlier reports [6], we also found that rhCG could prevent the development of diabetes.

Type 1 diabetes is a T cell-mediated autoimmune disease in both humans and NOD mice, in which activated Th1type $\mathrm{CD}^{+}$and $\mathrm{CD} 8^{+} \mathrm{T}$ cells are believed to kill pancreatic

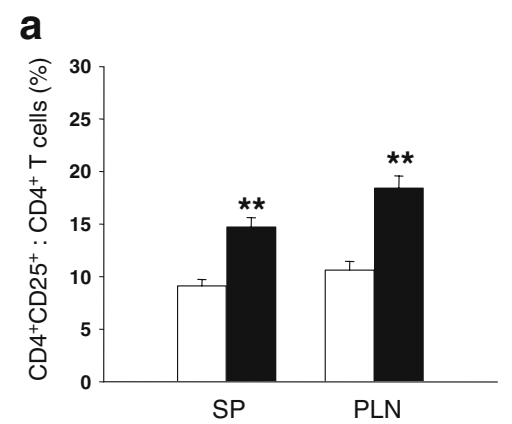

Fig. 5 Human $\mathrm{CG}$ treatment increases the ratio of $\mathrm{CD}^{+} \mathrm{CD} 25^{+} / \mathrm{CD}^{+}$ T cells. Splenocytes $(S P)$ or pancreatic lymph node cells $(P L N)$ from PBS-treated (open bars) or hCG-treated (closed bars) 10-week-old female NOD mice were double-stained with anti-CD4 and anti-CD25 were stimulated with $\mathbf{c}$ anti-CD3 antibody or $\mathbf{d}$ MIN6N8a cell extract. The stimulation index (SI) was determined by dividing the cpm from the stimulation group by that from the unstimulated group. Data are means \pm SEM. ${ }^{*} p<0.05 ;{ }^{* *} p<0.01$ compared with PBS-treated group, $n=10-12$ per group

beta cells by apoptosis $[9,10,18]$. Therefore, we examined the $\mathrm{T}$ cell population in hCG-treated NOD mice. Treatment of NOD mice with hCG decreased the number of $\mathrm{CD} 4^{+}$and $\mathrm{CD}^{+} \mathrm{T}$ cells. Consistent with this result, antigen-specific and non-specific $\mathrm{T}$ cell proliferation was inhibited by hCG. In addition, we found that hCG treatment decreased IFN- $\gamma$ production and increased the production of IL-10 and TGF$\beta$, suggesting that hCG may decrease the Th1 immune response. Taken together, these results indicate that treatment of NOD mice with hCG downregulates Th1-type $\mathrm{CD}^{+}$and $\mathrm{CD}^{+} \mathrm{T}$ cells. In addition to $\mathrm{T}$ cells, macrophages are important contributors to the destruction of beta cells in NOD mice. They achieve this by creating an immune environment that potentiates the Th1 response and by damaging beta cells with macrophage-derived soluble mediators such as IL- $1 \beta$, TNF- $\alpha$ and IFN- $\gamma$ [14]. We found that hCG treatment decreased LPS-stimulated TNF- $\alpha$ production, indicating that macrophage function is also downregulated, which may then decrease the Th1 immune response. In addition, the reduction of beta cell-toxic sub- b

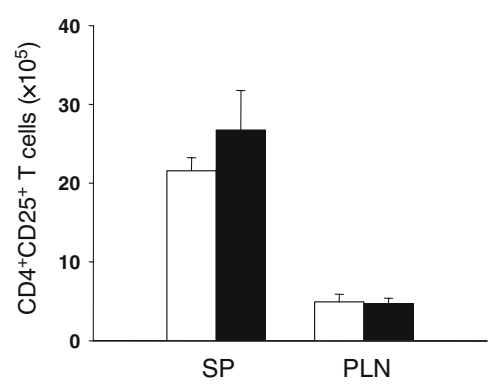

antibodies and analysed by FACS. a The proportion of $\mathrm{CD} 4{ }^{+} \mathrm{CD} 25^{+} \mathrm{T}$ cells as a percentage of total $\mathrm{CD}^{+} \mathrm{T}$ cells. b The number of $\mathrm{CD} 4{ }^{+} \mathrm{CD} 25^{+} \mathrm{T}$ cells. Data are means \pm SEM. ${ }^{* *} p<0.01$ compared with PBS treatment, $n=6$ per group 
a

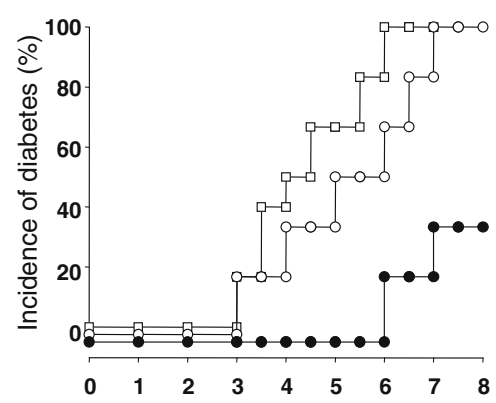

Time (weeks) after splenocyte transfer b

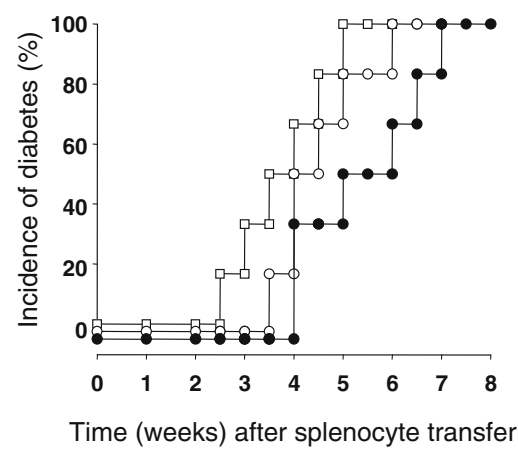

C

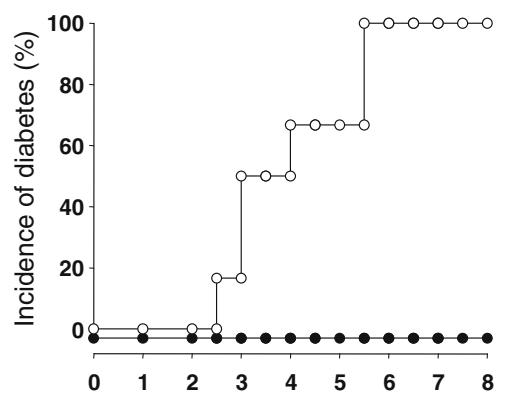

Time (weeks) after splenocyte transfer
Fig. $6 \mathrm{CD} 4^{+} \mathrm{CD} 25^{+}$regulatory $\mathrm{T}$ cells from hCG-treated mice are responsible for the prevention of diabetes. Splenocytes were isolated from PBS- or hCG-treated female NOD mice at 15 weeks of age. a $\mathrm{CD}^{+} \mathrm{T}$ cell-depleted splenocytes from PBS-treated (open circles) or hCG-treated (closed circles) mice were mixed with splenocytes from acutely diabetic NOD mice in a 2:1 ratio and injected intravenously into NOD.SCID mice. Splenocytes from diabetic mice were injected as a control (open squares). b $\mathrm{CD}^{+}$and $\mathrm{CD} 25^{+} \mathrm{T}$ cell-depleted

stances from macrophages may synergistically act to protect beta cells from destruction. It is known that TNF- $\alpha$ upregulates the transcription factors nuclear factor- $\mathrm{kB}$ and activator protein-1, resulting in the expression of a number of inflammatory response genes downstream of TNF- $\alpha$, and that in vivo treatment of cells with hCG downregulates TNF$\alpha$-induced nuclear factor- $\mathrm{kB}$ and activator protein-1 [19]. This could explain, in part, the preventive effects of hCG on beta cell destruction.

$\mathrm{CD} 8^{+} \mathrm{T}$ cell-depleted splenocytes from hCG-treated mice were able to substantially prevent the transfer of diabetes by splenocytes from acutely diabetic NOD mice (Fig. 6a), achieving a similar degree of prevention to that seen in recipients of total splenocytes from hCG-treated NOD mice (Fig. 2b). This suggests that hCG treatment may induce a splenocytes from PBS-treated (open circles) or hCG-treated (closed circles) mice were mixed with splenocytes and injected as in a. Control, as a (open squares). c CD25 ${ }^{+} \mathrm{T}$ cell-depleted splenocytes (open circles) or total splenocytes (closed circles) from hCG-treated mice were injected intravenously into NOD.SCID mice. The development of diabetes was monitored. $p<0.01$ (a) compared with recipients of CD8-depleted PBS splenocytes+diabetic splenocytes; $p<0.001$ (c) compared with recipients of CD25-depleted hCG splenocytes

regulatory $\mathrm{T}$ cell population that can prevent diabetes transfer and that the $\mathrm{CD} 4^{+} \mathrm{T}$ cell population may contain these regulatory $\mathrm{T}$ cells. Regulatory $\mathrm{T}$ cell numbers and function have been shown to be impaired in NOD mice [20, $21]$ and in human patients with type 1 diabetes or other autoimmune diseases [11]. Thus, we examined whether there were any changes in regulatory $\mathrm{T}$ cell populations, such as natural killer T cells, $\mathrm{CD} 4{ }^{+} \mathrm{CD} 62 \mathrm{~L}^{+} \mathrm{T}$ cells and $\mathrm{CD} 4^{+} \mathrm{CD} 25^{+}$ $\mathrm{T}$ cells. We found that only the $\mathrm{CD} 4{ }^{+} \mathrm{CD} 25^{+} \mathrm{T}$ cell population was significantly increased in hCG-treated NOD mice. An increase in the $\mathrm{CD} 4^{+} \mathrm{CD} 25^{+} \mathrm{T}$ cell population was also found in male NOD mice treated with hCG (data not shown). Although hCG treatment did not increase the absolute number of $\mathrm{CD} 4^{+} \mathrm{CD} 25^{+}$regulatory $\mathrm{T}$ cells, the increase in the ratio of $\mathrm{CD} 4^{+} \mathrm{CD} 25^{+} \mathrm{T}$ cells relative to $\mathrm{CD} 4^{+}$

Table 1 Comparison of recombinant hCG with purified hCG with regard to control of autoimmune diabetes in NOD mice

\begin{tabular}{llll}
\hline & PBS & hCG & rhCG \\
\hline Diabetes incidence $^{\mathrm{a}}$ & $10 / 12(83.3 \%)$ & $0 / 12(0 \%)^{* * * *}$ & $1 / 6(16.7 \%)^{*}$ \\
Diabetes incidence by adoptive transfer $^{\mathrm{b}}$ & $6 / 6(100 \%)$ & $0 / 6(0 \%)^{* * * *}$ & $0 / 6(0 \%)^{* * * *}$ \\
${\text { Production of cytokines }(\mathrm{ng} / \mathrm{ml})^{\mathrm{c}}}$ & & & \\
IFN- $\gamma(n=9)$ & $1.400 \pm 0.115$ & $0.764 \pm 0.077^{* * *}$ & $0.790 \pm 0.0921^{* *}$ \\
IL-4 $(n=7)$ & $0.129 \pm 0.011$ & $0.131 \pm 0.012$ & $0.133 \pm 0.013$ \\
TNF- $\alpha(n=5)$ & $0.479 \pm 0.076$ & $0.236 \pm 0.033^{*}$ & $0.287 \pm 0.030^{*}$ \\
\hline
\end{tabular}

Data are $n / n(\%)$ or means \pm SEM

${ }^{*} p \leq 0.05$

$* * p<0.01$

$* * * p \leq 0.005$

$* * * * p \leq 0.001$ compared with the PBS control

${ }^{\text {a }}$ Three-week-old female NOD mice were treated with hCG, rhCG or PBS and cumulative incidence of diabetes at 30 weeks of age determined, as described in Methods

${ }^{\mathrm{b}}$ The cumulative incidence of diabetes in NOD.SCID recipients of splenocytes isolated as described in Methods was determined at 8 weeks after transfer

${ }^{\mathrm{c}}$ The production of IFN- $\gamma$, IL-4 and TNF- $\alpha$ in splenocytes isolated as described in Methods was measured by ELISA 
T cells was able to inhibit the proliferation of effector T cells, as $\mathrm{CD} 4^{+} \mathrm{CD} 25^{+}$regulatory $\mathrm{T}$ cells are potent suppressors of activation of both $\mathrm{CD} 4^{+}$and $\mathrm{CD} 8^{+} \mathrm{T}$ cells $[22,23]$. Adoptive transfer of $\mathrm{CD} 44^{+} \mathrm{CD} 25^{+} \mathrm{T}$ cells can prevent the development of autoimmune thyroiditis, gastritis, inflammatory bowel disease and diabetes [24-26]. Moreover, $\mathrm{CD}^{+} \mathrm{CD} 25^{+} \mathrm{T}$ cells have been shown to play an important role in controlling the progression of type 1 diabetes in NOD mice [27-29]. Therefore, hCG may increase the ratio of $\mathrm{CD}^{+} \mathrm{CD} 25^{+} / \mathrm{CD}^{+}$ $\mathrm{T}$ cells, which could restore the immune balance between regulatory and effector $\mathrm{T}$ cells, resulting in the prevention of autoimmune disease. Depletion of $\mathrm{CD}^{+} \mathrm{CD} 25^{+} \mathrm{T}$ cells resulted in complete loss of the preventive effect of splenocytes from hCG-treated NOD mice, indicating that $\mathrm{CD} 4^{+} \mathrm{CD} 25^{+} \mathrm{T}$ cells play a role in the prevention of autoimmune diabetes by hCG treatment. It is possible that the increase in IL-10 and TGF- $\beta$ in hCG-treated mice may contribute to the increased ratio of $\mathrm{CD} 4^{+} \mathrm{CD} 25^{+} / \mathrm{CD} 4^{+} \mathrm{T}$ cells, as it is known that these cytokines play an important role in the generation and function of $\mathrm{CD} 4^{+} \mathrm{CD} 25^{+}$regulatory $\mathrm{T}$ cells $[30,31]$. There is growing evidence that $\mathrm{hCG}$ can have a direct immunomodulatory effect on immune cells $[6,32]$. In this regard, we found from in vitro experiments that treatment of immune cells with hCG inhibited IFN- $\gamma$ and TNF- $\alpha$ production (L.-Y. Khil, H.-S. Jun and H. Kwon, unpublished results). However, we cannot exclude the possibility that hCG, which is a pleiotropic hormone, might also exert its immunosuppressive effects by modulating the level of other reproductive hormones such as progesterone and testosterone $[1,33,34]$ and thereby prevent the development of type 1 diabetes in NOD mice.

In this report, we have shown that hCG treatment: (1) downregulates $\mathrm{Th} 1$ cells, $\mathrm{CD} 8^{+} \mathrm{T}$ cells and macrophages; (2) upregulates Th2 cells; and (3) increases the ratio of $\mathrm{CD} 4^{+} \mathrm{CD} 25^{+} / \mathrm{CD}^{+} \mathrm{T}$ cells in the spleen and pancreatic lymph nodes, contributing to the prevention of autoimmune diabetes in NOD mice. These results raise the possibility that hCG, a subunit of hCG (e.g. beta hCG) or a molecule associated with hCG [6, 35-39] might be useful in the treatment of diseases characterised by immune deviation or abnormal cytokine release. Although NOD mice are widely used as an experimental model of human type 1 diabetes, caution must be exercised when extrapolating results from mice to humans.

Acknowledgements The authors thank B. Sun for islet histology and A. Kyle for editorial assistance. This work was supported by grants from the Canadian Institutes of Health Research (MA9584) and American Diabetes Association (1-04-ISLET-31) to J.-W. Yoon and H.-S. Jun.

Duality of interest The authors declare that there is no duality of interest associated with this manuscript.

\section{References}

1. Healy DL (1987) Placental endocrinology. In: Gold JJ, Josimovich JB (eds) Gynecologic Endocrinology, 4th ed. Plenum, New York, pp 23-52

2. Da Silva JA, Spector TD (1992) The role of pregnancy in the course and aetiology of rheumatoid arthritis. Clin Rheumatol 11:189-194

3. Castiglione F, Pignata S, Morace F et al (1996) Effect of pregnancy on the clinical course of a cohort of women with inflammatory bowel disease. Ital J Gastroenterol 28:199-204

4. Confavreux C, Hutchinson M, Hours MM, Cortinovis-Tourniaire P, Moreau T (1998) Rate of pregnancy-related relapse in multiple sclerosis. Pregnancy in Multiple Sclerosis Group. N Engl J Med 339:285-291

5. Kruse N, Greif M, Moriabadi NF, Marx L, Toyka KV, Rieckmann $P$ (2000) Variations in cytokine mRNA expression during normal human pregnancy. Clin Exp Immunol 119:317-322

6. Khan NA, Khan A, Savelkoul HF, Benner R (2001) Inhibition of diabetes in NOD mice by human pregnancy factor. Hum Immunol 62:1315-1323

7. De SK, Wohlenberg CR, Marinos NJ, Doodnauth D, Bryant JL, Notkins AL (1997) Human chorionic gonadotropin hormone prevents wasting syndrome and death in HIV-1 transgenic mice. J Clin Invest 99:1484-1491

8. De SK, Devadas K, Notkins AL (2002) Elevated levels of tumor necrosis factor alpha (TNF-alpha) in human immunodeficiency virus type 1-transgenic mice: prevention of death by antibody to TNF-alpha. J Virol 76:11710-11714

9. Yoon JW, Jun HS (2005) Autoimmune destruction of pancreatic beta cells. Am J Ther 12:580-591

10. Bach JF, Chatenoud L (2001) Tolerance to islet autoantigens in type 1 diabetes. Annu Rev Immunol 19:131-161

11. Kukreja A, Cost G, Marker J, et al (2002) Multiple immunoregulatory defects in type-1 diabetes. J Clin Invest 109:131-140

12. Yoon JW, Yoon CS, Lim HW et al (1999) Control of autoimmune diabetes in NOD mice by GAD expression or suppression in beta cells. Science 284:1183-1187

13. Kawamura T, Nagata M, Utsugi T, Yoon JW (1993) Prevention of autoimmune type I diabetes by CD4+ suppressor T cells in superantigen-treated non-obese diabetic mice. J Immunol 151:4362-4370

14. Jun HS, Yoon CS, Zbytnuik L, van Rooijen N, Yoon JW (1999) The role of macrophages in T cell-mediated autoimmune diabetes in nonobese diabetic mice. J Exp Med 189:347-358

15. Ascoli M, Fanelli F, Segaloff DL (2002) The lutropin/choriogonadotropin receptor, a 2002 perspective. Endocr Rev 23:141-174

16. Buyon JP, Nelson JL, Lockshin MD (1996) The effects of pregnancy on autoimmune diseases. Clin Immunol Immunopathol 78:99-104

17. Wilder RL (1998) Hormones, pregnancy, and autoimmune diseases. Ann NY Acad Sci 840:45-50

18. Kurrer MO, Pakala SV, Hanson HL, Katz JD (1997) Beta cell apoptosis in $\mathrm{T}$ cell-mediated autoimmune diabetes. Proc Natl Acad Sci USA 94:213-218

19. Manna SK, Mukhopadhyay A, Aggarwal BB (2000) Human chorionic gonadotropin suppresses activation of nuclear transcription factor-kappa B and activator protein-1 induced by tumor necrosis factor. J Biol Chem 275:13307-13314

20. Wilson SB, Kent SC, Patton KT et al (1998) Extreme Th1 bias of invariant Valpha24JalphaQ $\mathrm{T}$ cells in type 1 diabetes. Nature 391:177-181

21. Falcone M, Yeung B, Tucker L, Rodriguez E, Sarvetnick N (1999) A defect in interleukin 12-induced activation and interferon gamma secretion of peripheral natural killer $\mathrm{T}$ cells in nonobese diabetic mice suggests new pathogenic mechanisms for insulindependent diabetes mellitus. J Exp Med 190:963-972 
22. Thornton AM, Shevach EM (1998) CD4+CD25+ immunoregulatory $\mathrm{T}$ cells suppress polyclonal $\mathrm{T}$ cell activation in vitro by inhibiting interleukin 2 production. J Exp Med 188:287-296

23. Levings MK, Sangregorio R, Roncarolo MG (2001) Human cd 25 $(+) \mathrm{cd} 4(+) \mathrm{t}$ regulatory cells suppress naive and memory $\mathrm{T}$ cell proliferation and can be expanded in vitro without loss of function. J Exp Med 193:1295-1302

24. Shevach EM (2000) Regulatory T cells in autoimmunity. Annu Rev Immunol 18:423-449

25. Read S, Malmstrom V, Powrie F (2000) Cytotoxic T lymphocyteassociated antigen 4 plays an essential role in the function of $\mathrm{CD} 25(+) \mathrm{CD} 4(+)$ regulatory cells that control intestinal inflammation. J Exp Med 192:295-302

26. Stephens LA, Mason D (2000) CD25 is a marker for CD4+ thymocytes that prevent autoimmune diabetes in rats, but peripheral $\mathrm{T}$ cells with this function are found in both CD25+ and CD25- subpopulations. J Immunol 165:3105-3110

27. Salomon B, Lenschow DJ, Rhee L et al (2000) B7/CD28 costimulation is essential for the homeostasis of the CD4+CD25+ immunoregulatory $\mathrm{T}$ cells that control autoimmune diabetes. Immunity 12:431-440

28. Pop SM, Wong CP, Culton DA, Clarke SH, Tisch R (2005) Single cell analysis shows decreasing FoxP3 and TGFbeta1 coexpressing $\mathrm{CD} 4+\mathrm{CD} 25+$ regulatory $\mathrm{T}$ cells during autoimmune diabetes. J Exp Med 201:1333-1346

29. Gregori S, Giarratana N, Smiroldo S, Adorini L (2003) Dynamics of pathogenic and suppressor $\mathrm{T}$ cells in autoimmune diabetes development. J Immunol 171:4040-4047

30. Chen ZM, O'Shaughnessy MJ, Gramaglia I et al (2003) IL-10 and TGF-beta induce alloreactive CD4+CD25- T cells to acquire regulatory cell function. Blood 101:5076-5083
31. Zheng SG, Wang JH, Gray JD, Soucier H, Horwitz DA (2004) Natural and induced CD4+CD25+ cells educate CD4+CD25cells to develop suppressive activity: the role of IL-2, TGF-beta, and IL-10. J Immunol 172:5213-5221

32. Komorowski J, Gradowski G, Stepien H (1997) Effects of human chorionic gonadotropin (hCG) and beta-hCG on oncostatin $\mathrm{M}$ release from human peripheral blood mononuclear cells in vitro. Cytobios 92:159-163

33. Devoto L, Kohen P, Vega M et al (2002) Control of human luteal steroidogenesis. Mol Cell Endocrinol 186:137-141

34. Filicori M, Fazleabas AT, Huhtaniemi I et al (2005) Novel concepts of human chorionic gonadotropin: reproductive system interactions and potential in the management of infertility. Fertil Steril 84:275-284

35. Lunardi-Iskandar Y, Bryant JL, Blattner WA et al (1998) Effects of a urinary factor from women in early pregnancy on HIV-1, SIV and associated disease. Nat Med 4:428-434

36. Lee-Huang S, Huang PL, Sun Y et al (1999) Lysozyme and RNases as anti-HIV components in beta-core preparations of human chorionic gonadotropin. Proc Natl Acad Sci USA 96:2678-2681

37. Khan NA, Khan A, Savelkoul HF, Benner R (2002) Inhibition of septic shock in mice by an oligopeptide from the beta-chain of human chorionic gonadotrophin hormone. Hum Immunol 63:1-7

38. Bisacchi D, Noonan DM, Carlone S, Albini A, Pfeffer U (2002) Kaposi's sarcoma and human chorionic gonadotropin: mechanisms, moieties and mysteries. Biol Chem 383:13151320

39. Bassett R, De Bellis C, Chiacchiarini L et al (2005) Comparative characterisation of a commercial human chorionic gonadotrophin extracted from human urine with a commercial recombinant human chorionic gonadotrophin. Curr Med Res Opin 21:1969-1976 